\title{
Growth and biochemical composition of Chlorella vulgaris in different growth media
}

\author{
MATHIAS A. CHIA ${ }^{1}$, ANA T. LOMBARDI ${ }^{1}$ and MARIA DA GRAÇA G. MELÃ ${ }^{2}$ \\ ${ }^{1}$ Departamento de Botânica, Universidade Federal de São Carlos, \\ Rodovia Washington Luis, Km 235, 13565-905 São Carlos, SP, Brasil \\ ${ }^{2}$ Departamento de Hidrobiologia, Universidade Federal de São Carlos, \\ Rodovia Washington Luis, Km 235, 13565-905 São Carlos, SP, Brasil
}

Manuscript received on January 18, 2012; accepted for publication on April 3, 2013

\begin{abstract}
The need for clean and low-cost algae production demands for investigations on algal physiological response under different growth conditions. In this research, we investigated the growth, biomass production and biochemical composition of Chlorella vulgaris using semi-continuous cultures employing three growth media (LC Oligo, Chu 10 and WC media). The highest cell density was obtained in LC Oligo, while the lowest in Chu medium. Chlorophyll $a$, carbohydrate and protein concentrations and yield were highest in Chu and LC Oligo media. Lipid class analysis showed that hydrocarbons (HC), sterol esthers (SE), free fatty acids (FFA), aliphatic alcohols (ALC), acetone mobile polar lipids (AMPL) and phospholipids (PL) concentrations and yields were highest in the Chu medium. Triglyceride (TAG) and sterol (ST) concentrations were highest in the LC Oligo medium. The results suggested that for cost effective cultivation, LC Oligo medium is the best choice among those studied, as it saved the cost of buying vitamins and EDTA associated with the other growth media, while at the same time resulted in the best growth performance and biomass production.
\end{abstract}

Key words: carbohydrates, lipid class, microalgae, proteins.

\section{INTRODUCTION}

The understanding of microalgal ecophysiology is important for the understanding of phytoplankton fate in natural ecosystems, but also for optimizing the production of microalgal biomass in large scales with applications in aquaculture, bioenergy and cosmetic industry, among others. One of the first applications of microalgal biomass has been in aquaculture (Milledge 2011). It is known that the use of microalgae by fish larvae enhances their reproduction, giving the animals better

Correspondence to: Mathias Ahii Chia

E-mail: chia28us@yahoo.com immune system and health (Spolaore et al. 2006). Similarly, the substitution of artificial enrichment to rotifers by microalgae, a natural diet, has proved to give good results in productions systems (Whyte et al. 1994, Ferreira et al. 2009). Gouveia et al. (2002) showed that Chlorella vulgaris can be used for the pigmentation of the gilthead seabream (Sparus aurata).

However, in recent years microalgal studies have gained more attention. The use of Haematococcus pluvialis for commercial productions of astaxanthin is already a reality, and encapsulated dried biomass of $C$. vulgaris 
and Spirulina platensis as neutraceuticals are commercialized. All these applications can benefit from physiological investigations on microalgae, aiming at defined biochemical composition.

Although there are several large scale production systems for microalgae, their production is subject to high cost problems, and several approaches have been proposed for costs reduction, such as industrial/sewage effluent. However, if microalgal use is directed to the food, pharmaceutical or cosmetic industry, there is the need for keeping the microorganisms under clean conditions, free of environmental contaminants. Clearly, for such industries, effluents cannot be used to grow microalgae because they will accumulate contaminants, meaning that there is the need for culture medium selections.

It is known that microalgae respond with physiological alterations to the environmental conditions where they grow (Valenzuela-Espinoza et al. 2002, Scragg et al. 2002). This behavior can be viewed as a biotechnological attribute that can be manipulated in order to control the algae biochemical composition and growth, focusing on specific compounds and higher productivity. Therefore, the selection of cheap and promising media to improve microalgae production yield is of great interest. Harrison and Berges (2005) proposed that three main experimental categories, culture maintenance, algal biomass yield and physiological/growth experiments are a good way to search for ideal production conditions. Growth rates give a general index of algal health status and physiological condition in the cultures, since it reflects algal metabolism, as a response to all of its cellular cycles (Lombardi and Maldonado 2011). From this rationale, it is clear that batch cultures can offer adequate growth conditions for microalgae only during a short period of time, after which cell metabolism begins to collapse and photosynthesis is reduced (Lombardi and Maldonado 2011).
Several culture systems have been put forward as alternatives to the batch cultures for microalgae biomass production and physiological investigations (Ferreira et al. 2009). Continuous and semi-continuous cultures have gained attention because they not only provide a constant source of microalgal biomass, but also permit precise manipulation of their biochemical composition (Parrish and Wangersky 1987, Lombardi and Wangersky 1991, Ferreira et al. 2009). In the present research, we used semi-continuous cultures that provide steady-state growth conditions to investigate the biochemical composition (protein, lipids and carbohydrates) of Chlorella vulgaris. Iatroscan TLC-FID was used for lipid class analysis of the biomass kept in different growth media. The results showed that different culture media lead to different biochemical composition (lipids, proteins and carbohydrates) and growth yield in C. vulgaris sampled in healthy growth situations for all culture media tested.

\section{MATERIALS AND METHODS}

\section{Cultures}

The Chlorella vulgaris strain used was kindly provided by Prof. Dr. Armando A. H. Vieira from the freshwater microalgae culture collection of the Botany Department, Universidade Federal de São Carlos (UFSCar), Brazil. In the laboratory, it was cultured in three different growth media: half-strength $\mathrm{Chu} 10$ (Chu) (Nalewajko and O’Mahony 1989), WC medium (WC) (Guillard and Lorenzen 1972), and LC Oligo medium (LC Oligo) (AFNOR 1980).

The experiments were carried out in $500 \mathrm{~mL}$ polycarbonate Erlenmeyer flasks containing $200 \mathrm{~mL}$ of culture kept semi-continuously under controlled conditions of light intensity $\left(150 \mu \mathrm{mol} . \mathrm{m}^{-2} \cdot \mathrm{s}^{-1}\right)$, light/dark cycle (16:8 hours), and temperature $\left(20+2^{\circ} \mathrm{C}\right)$. Before beginning the experiments, C. vulgaris cells were acclimated to the specific 
growth medium in batch culture system. This acclimation consisted of culture transfers at exponential growth phase and monitoring each new culture for its growth rate. After 3 statistically similar consecutive growth rates, the microalgae were considered to be acclimated and reflecting each treatment concentration in the culture media to be tested. From this condition, the experimental semi-continuous cultures began. An initial cell density of $\sim 10^{5}$ cells. $\mathrm{mL}^{-1}$ was used for all treatments. Semi-continuous culture was achieved by removal/replacement of culture medium with the same volume of fresh medium according to the growth rate. This was performed by keeping cell density constant throughout the experimental period. The growth of all cultures was monitored spectrophotometrically at $684 \mathrm{~nm}$ with a Hach DR 5000 spectrophotometer (HACH, Loveland, Colorado, USA). The specific growth rates $(\mu)$ were calculated according to the equation below adapted from Lombardi and Maldonado (2011) for semi-continuous culture systems.

$\mu=\log \left(\frac{\operatorname{ABS}(t 2)}{\operatorname{axABS}(t 1)}\right)(t 2-t 1)^{-1}$

Where

$a=\frac{T_{v o l}-R_{v o l}}{T_{v o l}}$

Note: $\mathrm{ABS}=$ absorbance, $\mathrm{t}=$ time, $T_{\text {vol }}=$ total volume and $R_{\text {vol }}=$ removed/replaced volume.

Cell densities were determined through cell counts under optical microscope using an improved bright lined Neubauer haemocytometer. Algal dry weight was determined gravimetrically with the aid of a Sartorius MC21S analytical balance (Precision Weighing Balances, Bradford, MA), using 0.45 $\mu \mathrm{m}$ pore size cellulose acetate membrane filters (Millipore, Brazil) dried at $60^{\circ} \mathrm{C}$ for $24 \mathrm{~h}$.

Biomolecule yield (Qv) was obtained from the product of concentration per cell at the moment of sampling and the specific growth rate $(\mu)$.
$\mathrm{Qv}=\mu \mathrm{X}$

Where $\mathrm{X}$ is the biomolecule concentration in pg cell ${ }^{-1}$ and $\mu$ is the specific growth rate per day.

All reagents used in the experiments were of analytical grade and better. The experiments were performed in three replicates. Growth media $\mathrm{pH}$ was adjusted to $\mathrm{pH} 7$ before being sterilized by autoclaving at $121^{\circ} \mathrm{C}$ for $20 \mathrm{~min}$. All plastic and glassware used for the experiments were washed with neutral detergent and rinsed with distilled and deionized water. Further, they were left for 7 days in $10 \% \mathrm{HCl}$. All laboratory materials were rinsed with bi-distilled and ultrapure water $(18.2 \mathrm{~m} \Omega-\mathrm{cm}$, EasyPure II, Thermo Scientific, USA) before use.

\section{ANALYTICAL METHODS}

The extraction and analysis of chlorophyll $a$ were done according to the procedure of Shoaf and Lium (1976), and quantification was done with the equation of Jeffrey and Humphrey (1975).

Samples for protein and carbohydrate analysis were centrifuged at $1,500 \mathrm{rpm}$ for $10 \mathrm{~min}$. The pellet was kept at $-20^{\circ} \mathrm{C}$ until analysis. Intracellular carbohydrates were determined using the modified phenol-sulfuric acid method (Liu et al. 1973) with glucose as standard. Total intracellular protein was determined according to the procedure of Bradford (1976) using bovine serum albumin (BSA) as standard; protein extraction followed the protocol of Rausch (1981).

Lipids were extracted according to the modified method of Folch as described in Parrish (1999), which uses dichloromethane:methanol:water (2:1:0.75). Samples $(50 \mathrm{~mL})$ were filtered through $\mathrm{GF} / \mathrm{C}$ filters that were previously kept in a muffle furnace at $400^{\circ} \mathrm{C}$ overnight. Immediately after filtration samples were spiked with a known concentration of an internal standard (Hexadecan3-one, Sigma Aldrich). The filter was then sonicated for 2 minutes and centrifuged. Altogether, the supernatants were concentrated under $\mathrm{N}_{2}$ to a final 
volume of approximately $20 \mu \mathrm{L}$ and spotted on silica gel-coated quartz rods (Chromarods-SIII). On every extraction day, procedural blanks were performed on baked filters using ultrapure water.

Lipid class analysis was performed using an Iatroscan TLC-FID MK6S system according to Parrish (1999). Peak identification was done through calibration curves made with 9 lipid standards: n-nonadecane (aliphatic hydrocarbon, HC), cholesteryl palmitate (wax esters/steryl ester, WE/SE), n-hexdecan-3-one (ketone, KET), glyceryl tripalmitate (triglyceride, TAG), palmitic acid (free fatty acids, FFA), 1-hexadecanol (free aliphatic alcohol, ALC), cholesterol (free sterol, ST), 1-monopalmitoyl-rac-glycerol (acetone mobile phase lipids, AMPL) and 1,2, di-0-hexadecyl-snglycerol-3-phosphatidylcholine (phospholipids, PL). All lipid standards were obtained from SigmaAldrich (USA). Total lipid concentration in each extract was calculated by adding the concentrations of the different lipid classes. On each day of analysis, one rod chosen at random was used to develop a composite lipid standard, hence obtaining the retention values for each lipid class under daily conditions. All analyses were done with three replicates. Iatroscan settings were: hydrogen flow of $173 \mathrm{~mL} \cdot \mathrm{min}^{-1}$, air flow $2 \mathrm{~L} \cdot \mathrm{min}^{-1}$ and scan speed of $4 \mathrm{~mm} \cdot \mathrm{s}^{-1}$. All GF/C filters, glasswares, and metal materials that came into contact with the samples were previously baked overnight at $400^{\circ} \mathrm{C}$; Teflon ${ }^{\circledR}$ and glass materials were rinsed with acetone and then dichloromethane immediately before use to reduce contaminations. All reagents were of chromatographic (HPLC) grade.

\section{CONCENTRATIONS OF FREE IONS}

As culture media composition varies, with some including the addition of synthetic ligands while others do not, it is expected that variation in nutrients availability especially trace metals will occur. To be able to evaluate this effect as a possible cause of variation in algal metabolic response, we used the chemical equilibrium software $\mathrm{MINEQL}^{+}$version 4.62.3 to calculate the free ions concentrations of copper $(\mathrm{Cu})$, zinc $(\mathrm{Zn})$ and iron $(\mathrm{Fe})$, which are important trace elements for algae metabolism.

\section{DATA ANALYSIS}

One way analysis of variance (ANOVA) with Tukey's HSD post hoc test were used to test for significant differences among the growth parameters, biomass production and biochemical composition obtained through the different culture media. Relationship between the measured parameters was established using principal component analysis (PCA). Principal component analysis was done using the PAST version 2.09 for windows statistical software, while ANOVA was done using SPSS version 17 for windows.

\section{RESULTS}

The MINEQL ${ }^{+}$chemical equilibrium calculations for $\mathrm{Cu}, \mathrm{Fe}$ and $\mathrm{Zn}$ showed that the lowest free and labile $\mathrm{Cu}$ concentrations were present in the WC medium, which can be expected due to the presence of the synthetic organic ligand, EDTA. In general, our results showed that for the speciation of $\mathrm{Cu}$, $\mathrm{Zn}$ and $\mathrm{Fe}$, LC Oligo had the highest values, while WC the lowest and Chu 10 medium presented intermediate concentrations of both labile and free metal ions (Table I).

TABLE I

$\mathrm{MINEQL}^{+}$metal speciation results for selected elements in the growth media. Values are in $\mathrm{pCu}, \mathrm{pFe}$ and $\mathrm{pZn}$, where $p=$ negative base $\log _{10}$ of the molar concentrations.

\begin{tabular}{ccccc}
\hline \multirow{2}{*}{ Element } & Speciation & Chu 10 & LC Oligo & WC \\
\hline \multirow{2}{*}{ Copper } & Free & 9.56 & 7.76 & 12.84 \\
& Labile & 9.91 & 8.03 & 8.72 \\
\cline { 2 - 5 } Iron & Free & 5.62 & 5.52 & 5.89 \\
& Labile & 7.09 & 6.05 & 6.96 \\
\cline { 2 - 5 } Zinc & Free & 9.11 & 7.03 & 10.03 \\
& Labile & 10.80 & 8.53 & 11.49 \\
\hline
\end{tabular}


Biomass results are shown in Fig. 1. The highest algal growth (Fig. 1a) and cell density (Fig. 1b) were obtained in the LC Oligo medium. C. vulgaris growth rates obtained for the culture media tested were: LC Oligo: $0.84 \mathrm{~d}^{-1}$, Chu: $0.79 \mathrm{~d}^{-1}$ and WC:0.62 $\mathrm{d}^{-1}$ media.
Dry weight production and yield (pg.cell-1) were highest in the LC Oligo medium and lowest in the WC medium (Fig. 1c). Chlorophyll $a$ production and yield were highest in the Chu medium and lowest in the WC medium (Fig. 1d).
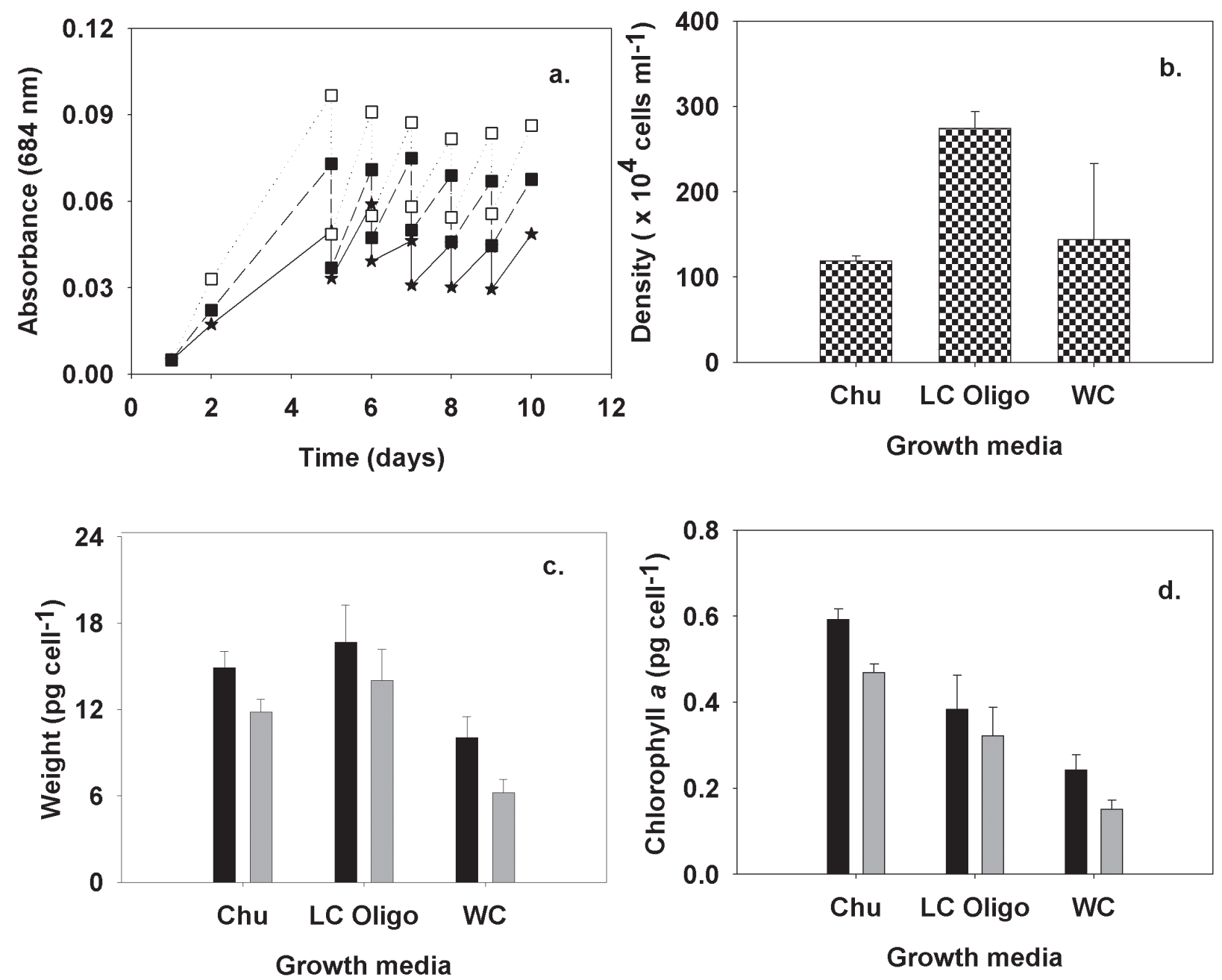

Figure 1 - (a) Growth curve (star: WC; open square: LC Oligo; filled square: Chu) and specific growth rates $\left(\mathrm{d}^{-1}\right)$ for Chu $(0.79)$, LC Oligo (0.84) and WC (0.62 $\left.\mathrm{d}^{-1}\right)$; (b) cell density (cells. $\left.\mathrm{mL}^{-1}\right)$; (c) dry weight (pg.cell $\left.{ }^{-1}\right)$, and (d) chlorophyll $a$ production (black bars) and yield (gray bars) (pg.cell ${ }^{-1}$ ) for Chlorella vulgaris grown in Chu (Chu medium), WC (WC medium), LC Oligo (LC Oligo medium). Error bars represent standard deviation for $n=3$.

Total intracellular proteins, carbohydrates and lipids results are shown in Fig. 2. The lowest protein, carbohydrate and lipid concentrations and yields were obtained in C. vulgaris grown the LC Oligo medium, while the highest was found in the Chu medium. Lipid class composition analysis showed that HC,
SE, FFA, ALC, AMPL and PL concentrations and yields were highest in the $\mathrm{Chu}$ medium, while the lowest value was recorded in the WC medium (Fig. 3). Lipid class composition and total lipid production did not significantly $(P<0.05)$ differ between the LC Oligo medium and Chu 10 medium. 

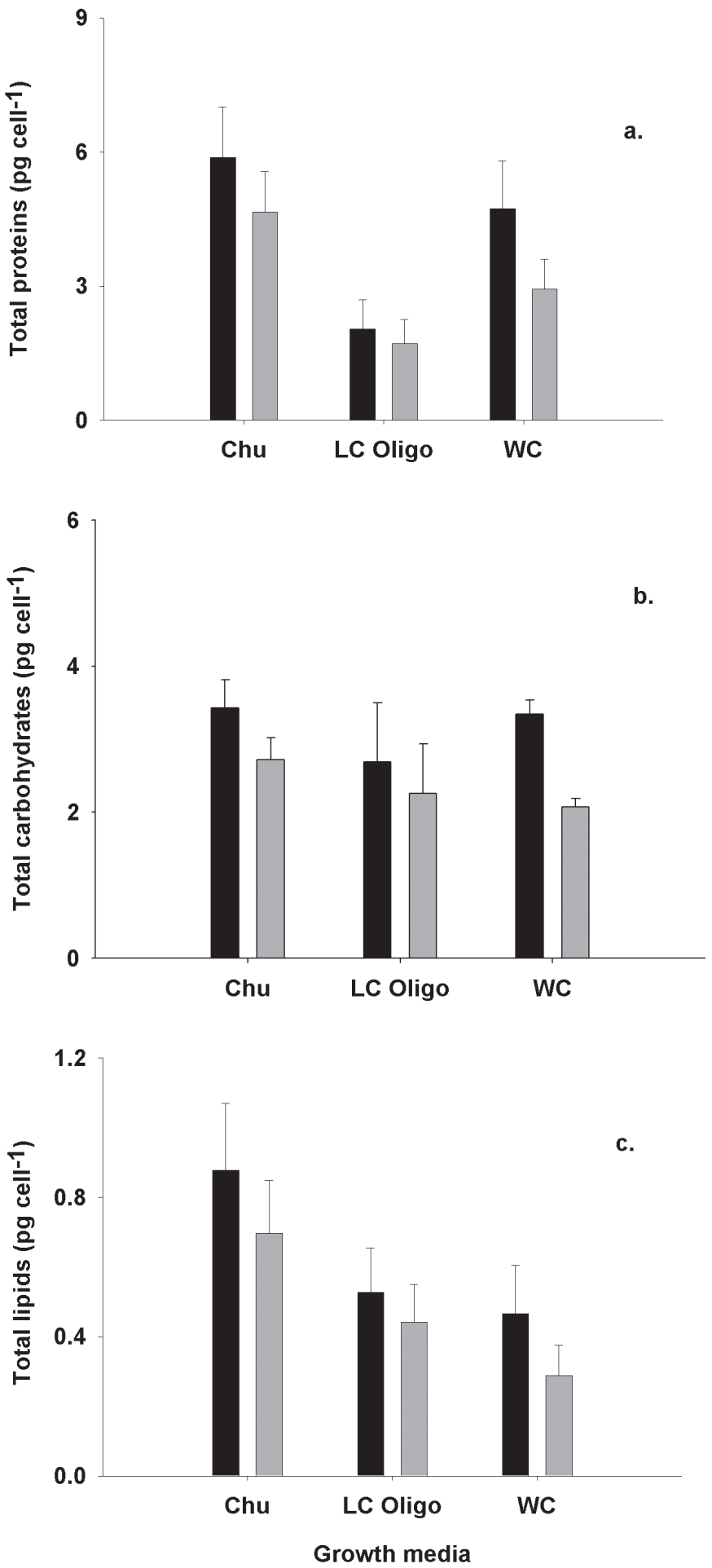

Figure 2 - Total carbohydrate (a), total protein (b) and total lipid (c) production (black bars) and yield (gray bars) (pg.cell ${ }^{-1}$ ) of Chlorella vulgaris as a function of media type using semi continuous culture system. Error bars represent standard deviation for $n=3$. Chu $=\mathrm{Chu}$ medium, $\mathrm{WC}=\mathrm{WC}$ medium, LC Oligo $=$ LC Oligo medium. 
Principal component analysis showed that the first two components accounted for $68 \%$ of the total variation observed in the PCA (Fig. 4). Phosphorus and nitrogen concentrations were positively correlated with SE, TAG, FFA, ALC, and ST concentrations. In addition, P was significantly $(p<0.05)$ associated with cell density, dry weight, chlorophyll $a$, AMPL, total lipids and carbohydrate concentration. Chlorophyll $a$ concentrations were positively correlated with AMPL levels. The concentration of the storage lipid class (TAG) was negatively correlated with the structural lipid class (PL) concentrations.

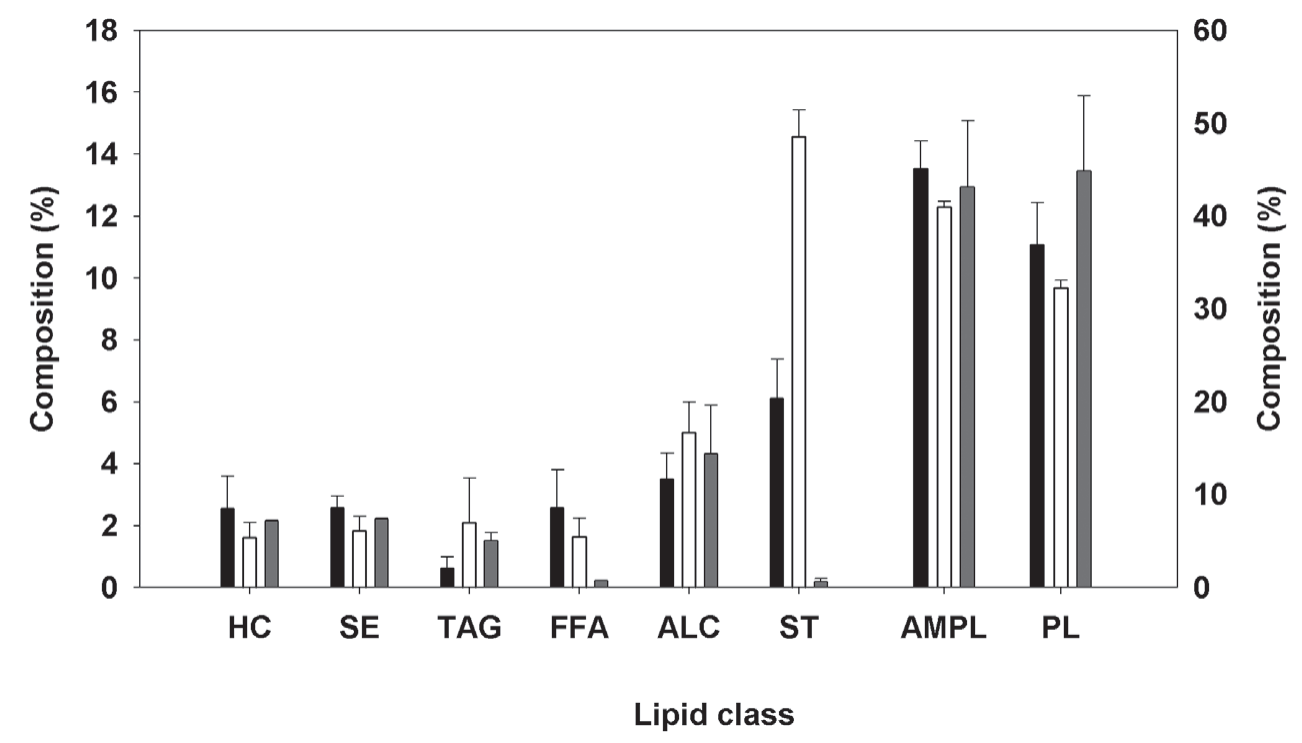

Figure 3 - Lipid class composition (\%) of Chlorella vulgaris grown in different growth media (black bars: Chu; white bars: LC Oligo; gray bars: WC). Neutral lipids are represented by HC, SE/WE, TAG, FFA, ALC and ST, and polar lipids by AMPL and PL. Error bars represent standard deviation for $n=3$. $\mathrm{Chu}=\mathrm{Chu}$ medium, $\mathrm{WC}=\mathrm{WC}$ medium, $\mathrm{LC}$ Oligo $=\mathrm{LC}$ Oligo medium. Right axis applies to AMPL and PL classes.

\section{DISCUSSION}

\section{GROWTH AND BIOMASS PRODUCTION}

Growth performance was influenced by media type, supporting the significantly higher growth rate $\left(0.84 \mathrm{~d}^{-1}\right)$ for $C$. vulgaris in the LC Oligo medium in comparison with the other two culture media tested. This growth rate value is within those reported in literature for Chlorella vulgaris. Ong et al. (2010) obtained specific growth rates of $0.40-0.85 \mathrm{~d}^{-1}$ for Chlorella sp. grown in $\mathrm{f} / 2$ medium, which are higher than that reported in Obata et al. (2009) for C. vulgaris in enriched $\mathrm{C}$ medium under semi-continuous conditions $\left(0.40 \mathrm{~d}^{-1}\right)$.
Cell density, an important biomass parameter varied significantly from medium to medium with LC Oligo having almost twice $\left(2.74 \times 10^{6}\right.$ cells. $\mathrm{mL}^{-1}$ ) the value found in the other growth media we investigated. However, our results are similar to those of Scragg et al. (2002) and Obata et al. (2009) that also investigated the growth of $C$. vulgaris under controlled conditions.

Chlorophyll $a$ production by phytoplankton cells is known to vary with growth conditions; in our experiments, the maximum production of chlorophyll a by $C$. vulgaris was $1 \mu \mathrm{g} \cdot \mathrm{mL}^{-1}$ in the LC Oligo cultures. These results are lower than those reported by Chinnasamy et al. (2009), which showed that batch cultures of $C$. vulgaris grown in 


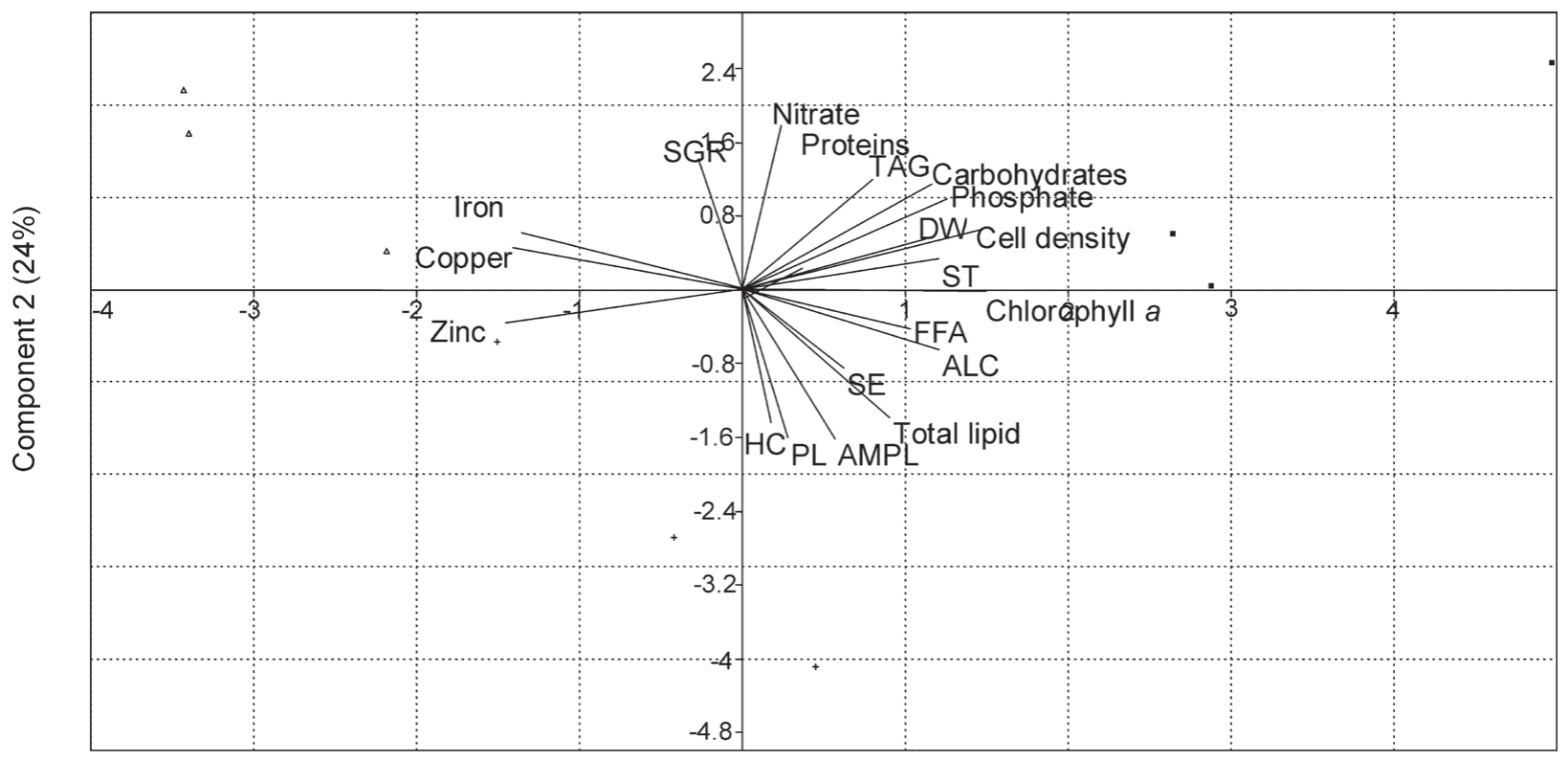

Component 1 (44\%)

Figure 4 - PCA biplot for the various parameters measured for Chlorella vulgaris cultured with different growth media using semi continuous culture. SGR = specific growth rate and DW = dry weight.

BG 11 medium, reached a maximum chlorophyll a concentration of approximately $5 \mu \mathrm{g} \cdot \mathrm{mL}^{-1}$ within the first 10 days. However, if the results are reported as chlorophyll a concentration per cell unit (not per volume), the present results show a high production for the Chu media cultures $\left(5.9 \times 10^{-13}\right.$ g.cell $\left.^{-1}\right)$, which are higher than those obtained by Bertoldi et al. (2008). These authors obtained a maximum chlorophyll a production for $C$. vulgaris grown in the BBM medium of $2.8 \times 10^{-13}$ g.cell ${ }^{-1}$.

The highest dry weight (16.82 pg.cell $\left.{ }^{-1}\right)$ concentration achieved using LC Oligo medium can be due to its composition, as this medium had the highest $\mathrm{N}$ and $\mathrm{P}$ concentrations. Similar to our study, Chinnasamy et al. (2009) obtained a dry weight production of about $50 \mu \mathrm{g} . \mathrm{mL}^{-1}$ during the exponential phase of $C$. vulgaris grown at $0.036 \%$ $\mathrm{CO}_{2}$ and $30^{\circ} \mathrm{C}$, which falls within the values (13-54 $\left.\mu \mathrm{g} . \mathrm{mL}^{-1}\right)$ obtained in this study in the media tested.

\section{BIOCHEMICAL COMPOSITION}

Proteins and carbohydrates concentrations were closely related to the media components like nitrate, phosphate and free copper ions. The protein production of $50 \%\left(7.0 \mathrm{mg} . \mathrm{L}^{-1}\right)$ in $\mathrm{Chu}$ and (6.8 mg. $\left.\mathrm{L}^{-1}\right)$ in WC media are higher than those obtained in other studies, but similar to the results of Bertoldi et al. (2008). Bertoldi et al. (2008) reported that $C$. vulgaris cultivated in BBM had a protein content of approximately 52.4\% (dry weight). However, Mahasneh (1997) showed that Chlorella sp. cultured in a medium containing 0.25 mg. $\mathrm{L}^{-1}$ phosphate had $15.7 \%$ protein, while with higher phosphate concentration $\left(0.50 \mathrm{mg} . \mathrm{L}^{-1}\right), 37 \%$ protein content (dry weight) was obtained. Our results for protein content in Chu and WC media are about twice higher than those reported by Illman et al. (2000), who showed 29\% (dry weight) protein production by $C$. vulgaris in Watanabe medium.

The highest carbohydrates production by $C$. vulgaris in the present conditions was obtained in the LC Oligo cultures $\left(7.36 \mu \mathrm{g} . \mathrm{mL}^{-1}\right)$. Our results are similar to those reported in Habib et al. (2003). These authors showed a carbohydrate production of $30.8 \mathrm{~g}$ per $100 \mathrm{~g}$ of C. vulgaris grown in an NPK fertilizer enriched culture medium, while 
we obtained an equivalent of $33.74 \mathrm{~g}$ per $100 \mathrm{~g}$ C. vulgaris grown in Chu medium. Illman et al. (2000) reported carbohydrate concentrations of up to $50 \%$ for $C$. vulgaris in Watanabe medium, which is higher than the highest value of $37 \%$ we obtained for the same alga in WC medium. The findings of our study showed that with semi-continuous grown cells, once appropriate culture conditions are used, high productivity can be sustained for long periods and the microalgal biomass so obtained will show constant biochemical composition that can be further controlled by manipulating environmental/ culture parameters in order to increase its nutritive value (Ferreira et al. 2009).

In relation to lipid production, not all lipid classes were affected by the culture medium used. Aliphatic hydrocarbons (HC), free fatty acids (FFA), free aliphatic alcohols (ALC) and sterol esters (SE) were within $5 \%$ of the total lipid production. This percent value is within the normal range expected for most microalgae under healthy growth conditions independent of the culture medium (Hu 2004, US DOE 2010, Scarsella et al. 2010). According to Lombardi and Wangersky (1991), high values of FFA, greater than $5 \%$, are probably the result of the action of lipases freed during sample preparation, and should be interpreted with caution.

In the present experiments, structural lipids, such as the AMPL and PL classes dominated the percent lipid composition in C. vulgaris independent of the culture medium used. Polar lipids (AMPL and PL) production of C. vulgaris under autotrophic and healthy growth are usually above $90 \%$ of the total lipids, while under heterotrophic and healthy growth the value is around $37 \%$ (Hu et al. 2008, Scarsella et al. 2010). These findings show that with autotrophic and semi-continuously grown C. vulgaris, high contribution of the polar lipids classes AMPL and PL are obtained. This is important for aquaculture when polar lipids contribute to the production of PUFAs through esterification in the polar lipids (Meireles et al. 2003); PUFAs are known as effective growth promoters in aquaculture (Ferreira et al. 2009, Hill et al. 2011). AMPL is a polar lipid class that may contain 35-50\% chlorophyll (Parrish and Wangersky 1987, Lombardi and Wangersky 1991, 1995, Illija et al. 2009). This in fact explains the significant correlation of chlorophyll a with the AMPL lipid class.

TAG lipid class in the present research was kept relatively low, within $2 \%$ of the total lipids, denoting cultures were healthy despite the differences in media composition. According to Lombardi and Wangersky (1991), TAG content can be a better guide to the physiological state of phytoplankton cells than is the $\mathrm{C}: \mathrm{N}: \mathrm{P}$ ratio, and any TAG content higher than $15 \%$ of the total lipids imply nutrient stress. The negative relationship between TAG and PL reflects the physiological route towards structural lipid synthesis that occurs under nutrient replete conditions, confirmed by the increase in biomass in these situations. This agrees with the results of Rodolfi et al. (2008) and Griffith and Harrison (2009) which shows that under nutrient replete conditions, the precursors involved in TAG and PL synthesis are channeled towards the production of PL, needed for cell membranes.

Total lipid production varied among the culture media tested in this research, being lowest in WC grown C. vulgaris, suggesting that cells were under healthy growth conditions. Literature data show that total lipid production can be affected by $\mathrm{N}: \mathrm{P}$ ratios in culture media, which for the ones used here were Chu 10:1; LC Oligo 10:1; WC 100:1. This phenomenon is well demonstrated in Wikfors (1986) who showed an increase in total lipid production in Dunaliella tertiolecta at N:P ratios of $\sim 15: 1$, but not at 30:1, thereby confirming the importance of media characteristics on the biochemical composition of phytoplankton with implications for their nutritional value (Griffith and Harrison 2009, Pittman et al. 2011).

We found that the percent total lipid yield was highest in the Chu medium, producing approximately $10.7 \mathrm{~g}$ lipids per $100 \mathrm{~g}$ dry algae, 
which is approximately twice the value of $5.9 \mathrm{~g}$ lipids per $100 \mathrm{~g}$ dry algae reported by Converti et al. (2009) for C. vulgaris grown in Bold's Basal Medium (BBM) using batch cultures after 14 days. However, lipid productivity obtained in the Chu and LC Oligo medium (1.5 mg.L $\left.\mathrm{L}^{-1} \cdot \mathrm{d}^{-1}\right)$ were lower than those reported in Widjaja et al. (2009) of about $4.2 \mathrm{mg} \cdot \mathrm{L}^{-1} \cdot \mathrm{d}^{-1}$ for $C$. vulgaris cultured in the modified Fritzgerald medium.

\section{CONCLUSIONS}

The overall yield of C. vulgaris grown in WC medium for most parameters measured was the lowest among the treatments; the highest cell density supported by the LC Oligo medium in relation to $\mathrm{Chu} 10$ and $\mathrm{WC}$ resulted in overall higher system productivity in LC Oligo cultures. This confirms that LC Oligo can be a cheaper and cost effective alternative to the other media due to the absence of vitamins and EDTA. The biochemical composition of the biomass notably differed among the media, and in some cases significant differences were obtained. The best biomass in terms of high total carbohydrates and lipid production was obtained in Chu 10 and LC Oligo media. The higher proportion of polar lipids classes (AMPL - acetone mobile polar lipids and PL - phospholipids) obtained in Chu 10 medium can have positive effects for growth, immunological and physiological performance of herbivores that are fed on C. vulgaris.

\section{ACKNOWLEDGMENTS}

The authors acknowledge Fundação de Amparo à Pesquisa do Estado de São paulo (FAPESP, 2008/03487-0; 2008/02078-9), and Conselho Nacional de Desenvolvimento Científico e Tecnológico (CNPq, 556588/2009-6) for research funding. In addition, the authors are grateful for the doctoral fellowship granted to Chia AM by TWASCNPq (190034/2009-2) and ABU Zaria-Nigeria that has enabled him carry out this study.

\section{RESUMO}

A necessidade de algas limpas e custo de produção baixo demanda as investigações sobre a resposta fisiologica das algas sob condições diferentes de crescimento. Nesta pesquisa, investigamos o crescimento, produção biomassa e composição bioquímica de Chlorella vulgaris cultivada em três meios de crescimento (LC Oligo, Chu 10 e WC). A maior densidade celular foi obtida em LC Oligo, enquanto mais baixo em meio $\mathrm{Chu} 10$. Concentrações e rendimentos de clorofila a, carboidratos e proteínas foram mais altas em meios de Chu e Oligo. Análise de classe lipidicas mostrou que as concentrações e rendimentos dos hidrocarbonetos (HC), ésteres de esterol (SE), ácidos graxos livres (FFA), álcoois alifáticos (ALC), lipídios polares móveis em acetona (AMPL) e fosfolipídios (PL) foram maiores no meio Chu. Triglicerídeos (TAG) e esterol livre (ST) foram maiores no meio LC Oligo. Os resultados sugerem que pra o cultivo rentável, LC Oligo é a melhor escolha entres os meios estudados, como ele salvou o custo de comprar as vitaminas e EDTA associados com os outros meios, enquanto, ao mesmo tempo resultou no melhor desempenho de crescimento e produção biomassa.

Palavras chave: carboidratos, classe lipídicas, microalgas, proteínas.

\section{REFERENCES}

AFNOR - ASSOCIATION FRANÇAISE DE NORMALISATION 1980. Essais des eaux. Determination de línhibition de Scenedesmus subspicatus par une substance. Norme experimentale T90-304.

Bertoldi FC, SANT'ANNA E AND Oliveira JLB. 2008. Chlorophyll content and mineral profile in the microalgae Chlorella vulgaris cultivated in hydroponic wastewater. Cienc Rural 38: 54-58.

BRADFORD M. 1976. A rapid and sensitive method for the quantitation of microgram quantities of protein utilizing the principle of protein-dye binding. Anal Biochem 72: 243-254.

Chinnasamy S, Ramakrishnan B, Bhatnagar A and Das KC. 2009. Biomass Production Potential of a Wastewater Alga Chlorella vulgaris ARC 1 under Elevated Levels of CO2 and Temperature. Int J Mol Sci 10: 518-532.

Converti A, CASAZza AA, ORTIZ EY, PEREgo P AND Borghi MD. 2009. Effect of temperature and nitrogen concentration on the growth and lipid content of Nannochloropsis oculata and Chlorella vulgaris for biodiesel production. Chem Eng Process 48: 1146-1151. 
FERreira M, COUTINHO P, SEIXAS P, FÁBrEGAS J AND Otero A. 2009. Enriching Rotifers with "premium" microalgae Nannochloropsis gaditana. Mar Biotechnol 11: 585-595.

Gouveia L, Choubert G, Gomes E, Pereira N, Santinha J AND EMPIS J. 2002. Pigmentation of gilthead seabream, Sparus aurata (L.1875) using Chlorella vulgaris (Chlorophyta, Volvocales) microalga. Aquac Res 33: 987-993.

GRIFFITHS MJ AND HARRISON STL. 2009. Lipid productivity as a key characteristic for choosing algal species for biodiesel production. J Appl Phycol 21: 493-507.

GUILLARD RRL AND LORENZEN CJ. 1972. Yellow-green algae with chlorophyllide c. J Phycol 8: 10-14.

Habib MAB, Yusoff FM, Phang SM And Mohamed S. 2003. Growth and Nutritional Values of Moina micrura fed on Chlorella vulgaris grown in digested palm oil mill effluent. Asian Fish Sci 16: 107-119.

HARRISON PJ AND BERGES JA. 2005. Marine culture media. In: Andersen RA (Ed), Algal Culturing Techniques, Elsevier Academic Press, p. 21-33.

HILL WR, RINCHARD J AND CZESNY S. 2011. Light nutrients and fatty acid composition of stream periphyton. Freshwater Biol 56: 1825-1836.

HU Q. 2004. Environmental effects on cell composition. In: RICHMOND A (Ed), Hand-book of Microalgal Culture, Oxford: Blackwell, p. 83-93.

Hu Q, SOMMERFEld M, JarVis E, GHIRARdi M, Posewitz M, SeIBERT M AND DARZINS A. 2008. Microalgal triacylglycerols as feedstocks for biofuel production: perspectives and advances. Plant J 54: 621-639.

ILliJA MI, INDY JR, YASUI H AND ITABASHI Y. 2009. Lipid class and fatty acid composition of a little know and rarely collected alga Exophyllum wentii Weber-van Bosse from Bali Island, Indonesia. J Oleo Sci 58: 103-110.

ILLMAN AM, SCRAGG AH AND SHALES SW. 2000. Increase in Chlorella strains calorific values when grown in low nitrogen medium. Enzyme Microb Tech 27: 631-635.

JefFrey SW AND HuMPHREY GF. 1975. New Spectrophotometric equations for determining chlorophylls $a, b, c 1$ and c2 in higher plants, algae, and natural phytoplankton. Biochem Physiol Pfl 167: 191-194.

LiU D, Wong PTS AND DutKa BJ. 1973. Determination of Carbohydrate in Lake Sediment by a modified PhenolSulfuric acid method. Water Res 7: 741-746.

LOMBARDI AT AND MALDONADO MT. 2011. The effects of copper on the photosynthetic response of Phaeocystic cordata. Photosynth Res 108: 77-87.

LOMBARDI AT AND WANGERSKY PJ. 1991. Influence of phosphorus and silicon on lipid class production by the marine diatom Chaetoceros gracilis grown in turbidostat cage cultures. Mar Ecol Prog Ser 77: 39-47.

LOMBARDI AT AND WANGERSKY PJ. 1995. Particulate lipid class composition of three marine phytoplankters Chaetoceros gracilis, Isochrysis galbana (Tahiti) and Dunaliella tertiolecta grown in batch culture. Hydrobiologia 306: 1-6.
MAHASNEH IA. 1997. Production of single cell protein from five strains of the microalga Chlorella $s p$ (Chlorophyta). Cytobios 90: 153-161.

MeIreles LA, Guedes AC AND Malcata FX. 2003. Lipid class composition of the microalga Pavlova lutheri: Eicosapentaenoic and Docosahexaenoic acids. J Agr Food Chem 51: 2237-2241.

MiLledge JJ. 2011. Commercial application of microalgae other than as biofuels: a brief review. Rev Environ Sci Biotechnol 10: 31-41.

NALEWAJKo C AND O’Mahony MA. 1989. Photosynthesis of algal cultures and phytoplankton following an acid $\mathrm{pH}$ shock. J Phycol 25: 319-325.

OBATA M, TODA T AND TAGUCHI S. 2009. Using chlorophyll fluorescence to monitor yields of microalgal production. $\mathrm{J}$ Appl Phycol 21: 315-319.

ONG S, KAO C, ChIU S, TsAi M AND LIN C. 2010. Characterization of the thermal-tolerant mutants of Chlorella sp. with high growth rate and application in outdoor photobioreactor cultivation. Bioresource Technol 101: 2880-2883.

PARRISH CC. 1999. Determination of total lipid, lipid classes, and fatty acids in aquatic samples. In: ARTS MT AND WAINMAN BC (Eds), Lipids in freshwater ecosystems, New York: Springer-Verlag, p. 4-20.

PARRISH CC AND WANGERSKY PJ. 1987. Particulate and dissolved lipid classes in cultures of Phaeodactylum tricornutum grown in cage culture turbidostats with a range of nitrogen supply rates. Mar Ecol Prog Ser 35: 119-128.

PITTMAN JK, DEAN AP AND OSUNDEKo O. 2011. The potential of sustainable algal biofuel production using wastewater resources. Bioresource Technol 102: 17-25.

RAUSCH T. 1981. The estimation of micro-algal protein content and its meaning to the evaluation of algal biomass I. Hidrobiologia 78: 237-251.

Rodolfi L, ZitTelli GC, Bassi N, Padovani G, Biondi N, Bonini G AND TREDICI MR. 2008. Microalgae for oil: strain selection, induction of lipid synthesis and outdoor mass cultivation in a low-cost photobioreactor. Biotechnol Bioeng 102: 100-112.

Scarsella M, Belotti G, De Filippis P And Bravi M. 2010. Study on the optimal growing conditions of Chlorella vulgaris in bubble column photobioreactors. Chem Eng T 20: 85-90.

SCRAGG AH, ILlman AM, CRDEN A AND SHAlES SW. 2002. Growth of microalgae with increased calorific values in a tubular bioreactor. Biomass Bioenerg 23: 67-73.

SHOAF WT AND LIUM BW. 1976. Improved extraction of chlorophyll $\mathrm{a}$ and $\mathrm{b}$ from algae using dimethyl sulfoxide. Limnol Oceanogr 21: 926-928.

SPOLAORE P, JoANnis-CASSAN C, DURAN E AND ISAMBERT A. 2006. Commercial applications of microalgae. J Biosci Bioeng 101: 87-96.

U.S. DOE. 2010. National Algal Biofuels Technology Roadmap. U.S. Department of Energy, Office of Energy Efficiency and Renewable Energy, Biomass Program. http://biomass. energy.gov. 
VALENZUEla-EsPinOZA E, MilláN-NúÑEZ R AND NúÑEZCEBrero F. 2002. Protein, carbohydrate, lipid and chlorophyll a content of Isochrysis aff. galbana (clone T-Iso) cultured with a low cost alternative to the $f / 2$ medium. Aquacult Eng 20: 135-147.

Whyte NJC, Clarke WC, GINTHER NG, Jensen JOT AND TOWNSEND LD. 1994. In fluence of composition of Brachionus plicatilis and Artemia on growth of larval sable fish (Anoplopoma fimbria Pallas). Aquaculture 119: 47-61.
WidjaJA A, ChiEn C AND JU Y. 2009. Study of increasing lipid production from fresh water microalgae Chlorella vulgaris. J Taiwan I Chem Eng 40: 13-20.

WIKFORS GH. 1986. Altering growth and gross chemical composition of two microalgal mulluscan food species by varying nitrate and phosphate. Aquaculture 59: 1-14. 